原著

\title{
カラム凝集法を用いた輸血検査における自動化の問題点 一血漿検体の有用性一
}

\begin{tabular}{|c|c|c|c|c|c|c|}
\hline 細川 美香 & 大西 & 修司 & 阿部 & 岡前 & 文子 & 山岡 \\
\hline 哲司 & 松崎 & 龍典 & 寺岡 & 岸本 & 裕司 & 福原 \\
\hline
\end{tabular}

(平成 12 年 10 月 6 日受付)

(平成 13 年 4 月 21 日受理)

\section{THE STUDY OF AUTOMATIC TRANSFUSION TEST USING COLUMN AGGLUTINATION TECHNOLOGY - THE APPLICATION OF PLASMA SAMPLES-}

\author{
Mika Hosokawa, Shuji Onishi, Misao Abe, Fumiko Okamae, Manabu Yamaoka, \\ Tetsuji Otani, Tatsunori Matsuzaki, Atsuko Teraoka \\ Yuji Kishimoto and Shirou Fukuhara \\ Department of Blood Transfusion, Kansai Medical University
}

\begin{abstract}
We introduced Auto-Vue (Ortho Co.), full automation system of column agglutination technology (CAT) to our range of routine tests in January 1999. Although it is advisable to use plasma samples when automation is a factor, it has been our practice to use serum in conventional tube technique (TT). We compared the titer of various antibodies of EDTA plasma with serum in the Auto-Vue examination and found no difference between them concerning sensitivity of detection. Next, we found that positive samples of self-controls were more numerous in the CAT method than in the TT. No instance of auto-antibody was detected in those samples whose self-controls were positive in CAT and negative in TT. Additionally, it was observed that higher globulin value, lower specific gravity of erythrocytes and higher leukocytes count were frequently associated with false positive results of self-controls in CAT. As a result, plasma samples were useful for detection of antibodies in the CAT method. These results allow for the standardization of transfusion tests, increasing the efficiency of tasks and returning the results of tests more rapidly than before by using the Auto-Vue system.
\end{abstract}

Key words : Serum, Plasma, Column agglutination technology, Automatic transfusion test system

最近の輸血検査業務は多様化とともに，複雑化 しており，より効率的な検查方法が求められてい る。 また，従来の試験管法 (TT) では検査技師間 の熟練度や凝集像の見方の違いから生じる個人差 の解消, 再現性の向上及び定量化などが課題と なっている．これらのことから，輸血検査の標準 化を目指した自動化機器導入の試みが各施設で進
められており ${ }^{1) ~ 5)}$ ，当院でも 1999 年 1 月から全自 動輸血検査システム Auto Vue (Ortho 社)による ルーチン検査を実施している，自動化にあたって は血漿検体を用いることが前提となるため，今回 血清と血漿を用いて Auto Vue を用いたカラム凝 集法（CAT）により検查を行い，自動化における 血漿検体の有用性を検討した。 また, CAT での自 


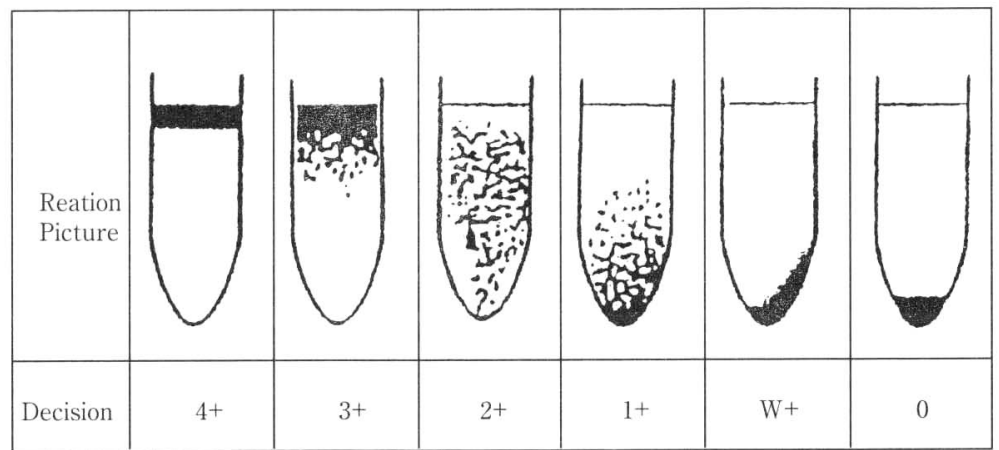

Fig. 1 Agglutination Reaction Patterns and Scoring Decision in Auto Vue

己対照陽性例についても TT と比較し, 血液検査 結果や病名をふまえて検討したので報告する。

\section{I 対象および方法}

CAT は Auto Vue の測定方法に従い ${ }^{6}$ 以下の検 討を行った（Fig. 1).

1）同種抗体検出における血清（プレイン採血）と 血漿（EDTA-2Na 採血）の比較

過去 2 年間に TT で同定した凍結 $\left(-40^{\circ} \mathrm{C}\right)$ 保 存検体 (抗 D 3 件, 抗 $\mathrm{E} 5$ 件, 抗 $\mathrm{E}+\mathrm{c}+\mathrm{Jk}^{\mathrm{a}} 1$ 件, 抗 $\mathrm{E}+\mathrm{Jk}^{\mathrm{b}} 1$ 件, 抗 $\mathrm{Jk}^{\mathrm{b}} 2$ 件, 抗 $\mathrm{Fy}^{\mathrm{a}} 1$ 件, 抗 $\mathrm{Fy}^{\mathrm{b}} 3$ 件, 抗 Le 2 件, 抗 M 2 件, 抗 S 2 件, 抗 $\mathrm{Di}^{\mathrm{a}} 3$ 件，抗 $\mathrm{Jr}^{\mathrm{a}} 2$ 件) を用い，血清は広範囲抗グロブリ ン抗体を充填したCAT 法 (Polyカセット法), 血 漿は抗 IgG 抗体を充填したCAT 法 ( $\operatorname{IgG}$ カセッ 卜法）で抗体価を測定した.

2）自己対照陽性検体の解析

(1) CATと TT の比較

不規則抗体スクリーニング検査依頼のあった 4,210 件を対象とし, IgGカセット法の自己対照 (CAT-A) 陽性検体について, TTで自己対照 [IAT (間接抗グロブリン試験)-A]の再検を行い,

また，TTの直接抗グロブリン試験（DAT）は全 例行い比較した。またTT陽性例については DT 解離法で抗体解離試験を実施した。

(2)血液検查結果による解析

a) CAT-A がW+のうち調查が可能であった 73 件中, 間接ビリルビンの増加 $(1 \mathrm{mg} / \mathrm{d} l$ 以上), 網赤血球の増加（3\% 以上），へモグロビン（Hb） の低下（男子 $12.5 \mathrm{~g} / \mathrm{d} l$ 未満, 女子 $11.5 \mathrm{~g} / \mathrm{d} l$ 未満）
を示す検体数を調査した。

b）CAT-A 陽性でIAT-A，DATとも陰性のう ち調查が可能であった 172 件と CAT-A 㓌性であ るものからランダムに選んだ 100 件について, 血 液生化学検查及び血液検査の結果を調查し比較し た。

(3)病名による解析

CAT-A 陽性でIAT-A, DAT とも陰性となった 患者の病名について調查した。患者によっては複 数の病名が存在するが，そのまま集計した。

\section{II 結 果}

1）同種抗体検出に扮ける血清と血漿の比較（Table 1)

検体 No. 12 の抗 E と No. 13 の抗 Jk ${ }^{\mathrm{b}}$ の抗体価 は血清で 2 管強く, No. 5,8 の抗 E, No. 16 の抗 M, No. 19 の抗 S, No. 20 の抗 Jk ${ }^{\mathrm{b}}$, No. 26 の抗 Dia 1 管強い反応を示した. 逆にNo. 10 の抗 c, No. 15 の抗 Le ${ }^{\mathrm{a}}$, No. 23 の抗 Fy ${ }^{\mathrm{b}}$, No. 30 の抗 Jra では血L 漿で 1 管強い反応を示した。 その他の検体は全て 一致した。

2）自己対照陽性検体の解析

(1)不規則抗体スクリーニング検査検体 4,210 件 中 CAT-A 陽性は 325 件 (陽性率 7.7\%) であった。 CAT-A 陽性のうち W + は 155 件 $(47.7 \%)$ で, そ れらは全てIAT-A, DAT陰性であった。また CAT-A で1+の 147 件 (45.2\%) 中にIAT-A 陽性 15 件, DAT 陽性 10 件を認め, このうち 6 件は抗 体解離試験で陽性を認めた。 CAT-A で $2+020$ 件 $(6.2 \%)$ 中ではIAT-A, DAT とも陽性が 13 
Table 1 The Comparison of The Titer of Antibodies in Serum and Plasma

\begin{tabular}{|c|c|c|c|c|c|c|c|}
\hline \multirow{2}{*}{ No. } & \multirow{2}{*}{ Antibody } & \multicolumn{2}{|c|}{ Titer } & \multirow{2}{*}{ No. } & \multirow{2}{*}{ Antibody } & \multicolumn{2}{|c|}{ Titer } \\
\hline & & Serum & Plasma & & & Serum & Plasma \\
\hline 1 & Anti D & 16 & 16 & 16 & Anti M & 16 & 8 \\
\hline 2 & Anti D & 16 & 16 & 17 & Anti M & 4 & 4 \\
\hline 3 & Anti D & 2 & 2 & 18 & Anti S & 32 & 32 \\
\hline 4 & Anti E & 8 & 8 & 19 & Anti S & 2 & 1 \\
\hline 5 & Anti E & 1,024 & 512 & 20 & Anti $\mathrm{Jk}^{\mathrm{b}}$ & 4 & 2 \\
\hline 6 & Anti E & 8 & 8 & 21 & Anti $\mathrm{Jk}^{\mathrm{b}}$ & 2 & 2 \\
\hline 7 & Anti E & 8 & 8 & 22 & Anti Fya & 4 & 4 \\
\hline 8 & Anti E & 4 & 2 & 23 & Anti Fyb & 4 & 8 \\
\hline$* 9$ & Anti $\mathrm{E}$ & 32 & 32 & 24 & Anti Fyb & 32 & 32 \\
\hline$* 10$ & Anti c & 8 & 16 & 25 & Anti Fyb & 4 & 4 \\
\hline$* 11$ & Anti $\mathrm{Jk}^{\mathrm{a}}$ & 8 & 8 & 26 & Anti $\mathrm{Di}^{\mathrm{a}}$ & 32 & 16 \\
\hline$\diamond_{12}$ & Anti E & 64 & 16 & 27 & Anti $\mathrm{Di}^{\mathrm{a}}$ & 2 & 2 \\
\hline$\diamond 13$ & Anti $\mathrm{Jk}^{\mathrm{b}}$ & 32 & 8 & 28 & Anti $\mathrm{Di}^{\mathrm{a}}$ & 2 & 2 \\
\hline 14 & Anti Le ${ }^{a}$ & 2 & 2 & 29 & Anti Jra & 64 & 64 \\
\hline 15 & Anti Le ${ }^{a}$ & 4 & 8 & 30 & Anti Jra & 2 & 4 \\
\hline
\end{tabular}

Serum : Poly (anti IgG $+\mathrm{C}_{3} \mathrm{~b}$ and $\mathrm{C}_{3} \mathrm{~d}$ ) cassette Plasma : IgG cassette

$*, \diamond:$ Found in The Same Sample

Table 2 The Comparison of Self Control in Auto Vue and in The Tube Test

\begin{tabular}{c|r|r|r|r|r|c}
\hline \multirow{2}{*}{ The Result } & \multirow{2}{*}{ CAT-A } & \multicolumn{5}{|c}{ Tube Test } \\
\cline { 3 - 7 } & & \multicolumn{2}{|c|}{ IAT-A } & \multicolumn{2}{|c}{ DAT } & $\begin{array}{c}\text { Elution } \\
\text { Test }\end{array}$ \\
\cline { 3 - 7 } & & - & + & - & + & + \\
\hline W+ & $155(47.7 \%)$ & 155 & 0 & 155 & 0 & \\
$1+$ & $147(45.2 \%)$ & 132 & 15 & 137 & 10 & 5 \\
$2+$ & $20(6.2 \%)$ & 7 & 13 & 7 & 13 & 3 \\
$3+$ & $2(0.6 \%)$ & 0 & 2 & 0 & 2 & 1 \\
$4+$ & $1(0.3 \%)$ & 0 & 1 & 0 & 1 & 1 \\
合計 & $325(100 \%)$ & 294 & 31 & 299 & 26 & \\
\hline
\end{tabular}

(The Positive Ratio of Self Control in Auto Vue:325/4,210=7.7\%)

件あり,このうち 3 件は抗体解離試験で陽性を認 めた. CAT-A で 3 +以上の 3 件 $(0.9 \%)$ はIATA, DAT でも全て陽性であり,このうち 2 件は解 離試験で陽性を認めた（Table 2).

解離試験陽性検体のうち 1 件はATG（Antithymocyte globulin) 投与による影響で，その他は 温式自己抗体保有患者であった。解離試験陰性検 体は抗生物質投与による影響のものと, IgG 高值 による IgGの非特異的な吸着と考えられるもの であった。
(2) a) CAT-A が W +の 73 件中, $\mathrm{Hb}$ の低下し ている検体は多く見られたが, 間接ビリルビンの 増加 $(1 \mathrm{mg} / \mathrm{d} l$ 以上）および網赤血球の増加（3 \%以上）を示す検体は 0 件であった。

b) CAT-A 陽性で, IAT-A, DAT 陰性の 172 件は CAT-A, IAT-A, DAT 全て陰性の 100 件と 比較して, 総蛋白・白血球数の平均值が有意に高 值を示し, 逆にアルブミン・ $\mathrm{A} / \mathrm{G}$ 比・ $\mathrm{Hb}$ ・平均 赤血球 $\mathrm{Hb}$ 濃度 $(\mathrm{MCHC})$ ・プロトロンビン時間 $(\mathrm{PT})$ ・ヘパプラスチンテスト $(\mathrm{HPT})$ の平均值は 

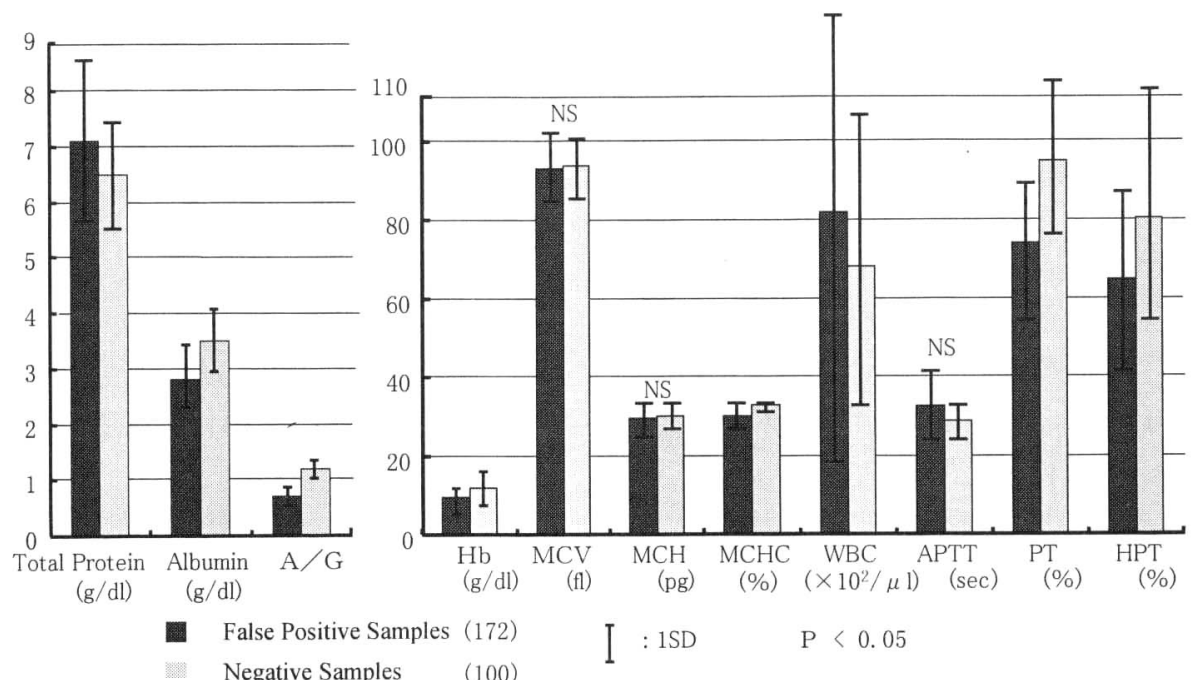

False Positive Sam
- Negative Samples

$(100)$

Fig. 2 The Laboratory Analysis of The Samples Whose Self Control Were Found

False Positive in Auto Vue

有意に低值を示した（Fig. 2).

(3) CAT-A 陽性で, IAT-A, DAT 陰性となった 295 例の病名を調査すると，固形癌が $18 \%$ に認め られ，肝癌の $15 \%$ と肝疾患の $12 \%$ を合わせると $45 \%$ となった. さらに糖尿病が $10 \%$, 鉄欠乏性貧 血が 8\%に認められた（Fig. 3).

\section{III 考察}

自動化にあたっては抗凝固剂入り検体が必須条 件で，それによって血漿を用いて検査を行わなけ ればならなくなったため，補体結合性抗体を見逃 す危険性を考える必要性が生じてきた。我々は Bio Vue $\mathrm{e}^{7 / 8)}$ 導入時にCATを用いて血清と血漿の 比較を行い, 補体結合性抗体と IgM 型抗体におい て若干の反応性が低下することを報告してお $\eta^{9)}$ ，道野らも反応が極めて微弱な抗 $\mathrm{Jk}^{\mathrm{b}}$ 抗体が 血清のみで反応を示し，血槳では検出できなかっ たと報告しているが，自動化のメリットを考慮す ると血漿に㧈ける不規則抗体検查は有用であると 附記している ${ }^{10)}$. しかし，血清と血漿検体の間で 不規則抗体の検出感度に差は認められないという 報告例もあり ${ }^{1112)}$ ，また Reis らも輸血副作用に関 連する臨床上重要な抗体が，従来の TTに扔ける 間接抗グロブリン試験において，抗補体成分を含

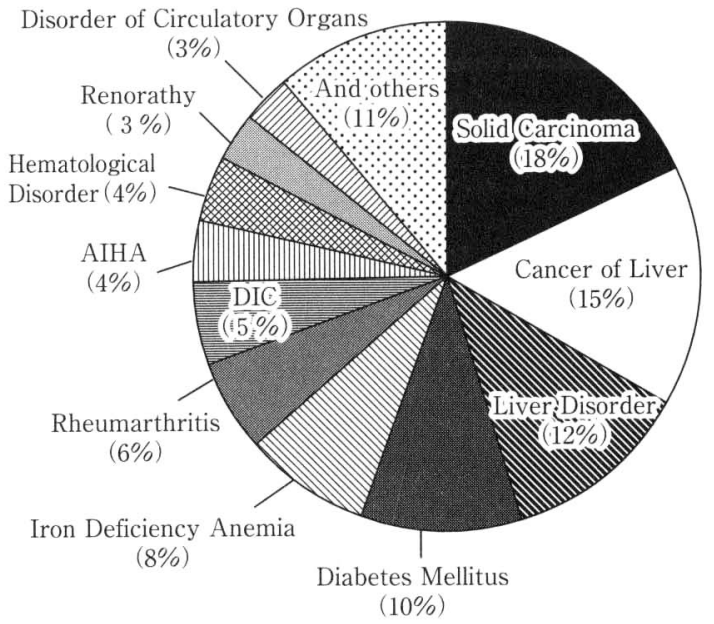

(False Positive Samples:294)

Fig. 3 The Disorders of The Patients Whose Self Control Were Found False Positive in Auto Vue

まない抗 IgG を使用した場合でも，広範囲抗グロ ブリン試薬を用いた場合と同等あるいはそれ以上 の感度で検出できることを証明している ${ }^{13}$. 我々 の検討では TT (血清) と CAT (血墏) の検出感 度を比較すると, TTのアルブミン/IAT法と CAT は同程度であるが, TT の PEG/IAT 法では 
やや感度が高いと考えられる. しかし, TT の判 定ではピペッティングや試験管の振り方などの技 術面以外に, 個人の注意力, 判断力, 観察力, 精 神状態や健康状態によっても判定結果に誤差が生 じる可能性がある. 今回我々が行った Auto Vue による CATでの血清検体と血漿検体の抗体価の 比較においては，いずれの抗体もその抗体価は 2 管差以内で有意な差は認められなかった。このこ とから, Auto Vue で血漿検体を用いた場合でも 臨床的意義のある抗体を見落とすことなく検出す ることができると思われ，客観性（複数の技師に よる判定), 再現性又は標準化などの観点から総合 的に考えると，むしろ血漿検体を用いた CAT の 有用性は TT と同程度あるいはそれ以上であると 考えられた.ささらに，抗凝固剂入り検体は血清分 離が困難な場合，特に緊急時の検査にも対応しゃ すいという利点もあった.

CAT-A は陽性率 7.7\% と高い傾向を認めたが, 約半数を占める $\mathrm{w}+(47.7 \%)$ のものは全例が IAT-A, DAT ともに陰性であり, 間接ビリルビ ン，網赤血球がともに増加しているような溶血所 見を示す検体もなかったことから偽陽性と推定し た.また判定 $1+$ 以上のものについては温式自己 抗体が含まれる可能性が示唆されたため, 精査が 必要であると考えられた。即ち CAT-A で陽性反 応を見落とすことはないが逆に感度が高すぎる傾 向があるため, 判定基準をどこに定めていくかは 各施設で検討しなければならない。 また，自己対 照偽陽性群では総蛋白が高值を示し, アルブミン ・A/G 比は低值を示すことからグロブリン高值 が示唆され，これはDATに比べCATでは赤血 球結合 IgG 分子数が少なくても陽性と判定され るという報告と一致する ${ }^{14) ~ 16)} . \mathrm{Hb} \cdot \mathrm{MCHC} に つ$ いては偽陽性群の方が低值で, 赤血球の比重が軽 いことによっても偽陽性になることが示唆され, Fig. 1 に示した偽陽性群の $8 \%$ に認められる鉄欠 そ性貧血もその一部と思われた。これはCATの 抗グロブリン法の原理に比重勾配遠心法が応用さ れているためと考えられた。また，白血球数では 偽陽性群の方が高值を示し, Buffy coatの混入に より白血球が検体採取後の時間経過とともに崩壊
してできた細胞の破片などが，ガラスビーズ通過 時に赤血球に付着したままトラップされる現象が 起こっているのではないかと考えられた. PT ・ HPT でも偽陽性群と陰性群とで差が認められた ことから，原因は明らかでないが凝固線溶系の異 常がみられる場合にも疑陽性になりやすいと思わ れ, 固形癌 $(18 \%)$, 肝癌 $(15 \%)$, 肝疾患 $(12 \%)$ および糖尿病 $(10 \%)$ など凝固線溶系の異常が知 られている疾患が, 偽陽性群に Total で $55 \%$ と多 くみられた傾向と一致する。

\section{IV まとめ}

輸血検査の自動化にあたっては抗凝固剤採血に よる検体を用いるため，抗体検出において血槳検 体であることに留意する必要性があるが，それを 考慮しつつ当院では Auto vue を用いた血液型・ 抗体スクリーニング検査を自動化することによ り, TT と比較しても検出感度を低下させること なく検査の標準化及び業務の効率化を図ることが できた．輸血検查の自動化においても，より安全 な輸血の実施を目的として, 機器や検査法などの 特性をよく理解し, 各施設で何が求められている のかを確認することが重要であると思われた。

\section{文献}

1) 平野武道：CAT 法における反応結果の標準化に ついての評価検討. 臨床検査機器・試薬, 20(6) : 879-888, 1997.

2) 寺岡敦子：当院における自動化機器導入の現状. 日本輸血学会誌, 45(6)：929-931, 1999.

3）押野政次 : Micro Typing System の基礎的検討 (II) 一抗体同定試験について一. 臨床検査機器 · 試薬, $17(2) ： 423-432,1994$.

4）山根和恵：不規則抗体スクリーニング用 Solid phase system (Capture-R Ready Screen)の基礎的 検討. 臨床検查機器・試薬 22(2) : 181-185, 1999

5）道野淳子：キャプチャーRレディ・スクリーン の使用経験一カラム凝集法との比較を中心に一. 臨床検查機器・試薬, 22（3）：275一281, 1999.

6) Ortho Auto Vue ${ }^{\mathrm{TM}}$ System user manual, オーソ • クリニカル・ダイアグノスティックス株式会社.

7) Dr. Bernard Lamy : BioVue A New Concept in Immunohematology. Translated and reprinted from originalarticle in ORTHO magazine No. 4 : 1992.

8) Bio Vue Scientific Monographs, 第 1 巻. Ortho- 
Clinical Diagnostics k.k., 1996.

9）石田萠子，他：輸血検査におけるカラム凝集法の 導入一取り扱い上の注意点一. 医学検査, 20 ： 863-874, 1997.

10）道野淳子，他：血嶈を用いた不規則抗体検査の試 み一自動化に向けて一. 日本輸血学会誌（第 45 回総会抄録集）：270, 1997.

11) Kitagawa, et al. : Donor Antibody Detection Using Plasma in Place of Serum. Transfusion, 19 (1) : 60-62, 1979

12) Chapman, J. F. : Five year experience of using plasma for antibody screeningand crossmatching. Transfusion Medicine : Vol. 4 Supple- ment : 35, 1994.

13) Reis, K.J., et al. : Column agglutination technology. Transfusion, $33: 639-643,1993$.

14）小山田隆，他：カラム凝集法による自己免疫性溶 血性貧血スクリーニングの有用性と問題点. 日本 輸血学会誌（第 46 回総会抄録集）：201, 1998.

15）近江俊徳, 他：温式自己免疫性溶血性負血におけ る赤血球結合 IgG 量の測定とその意義. 日本輸血 学会誌, $38 ： 601-606,1992$.

16）菅野直子，他：カラム凝集法による赤血球凝集反 応一試験管法, ビーズ法, ゲル法の比較検討一. 医学検査, $49(6): 951-955,2000$. 